\title{
A Study on Women's Preference To wards Mutual Fund Investments with Special Reference To Cochin.
}

\author{
${ }^{1}$ Ms.Deepthi George ${ }^{2}$ Dr.JagadeesChandran
}

\begin{abstract}
In this paper an attempt was made to get an idea about the preference of women investors towards mutual fund, their attitude towards MF investmentand to know the potential customers and their requirements. The study has been conducted on the basis of primary data and secondary data.Majorityof the investors opined better return and safety are the motives behind their investment. Only minor group of investors are ready to undertake high level of risk. And rest of them preferred to play a safe game. The study also proved that there is a significant relationship between period of investment and return.
\end{abstract}

Key words: Mutual fund, Women investor and Potential customers.

\section{INTRODUCTION}

Saving is the surplus of income over expenditure and when such savings are invested to generate more income, it is called investment. Hence savings and investments are closely linked with each other.Investors have different perception when they decide about investing in a particular avenue,every individual wants that their saving to be most secured and liquid avenue.However, the decision changes according to individual and their ability to take risk. There are a lots of investment avenues available today in the financial market for an investor. They can invest in Bank Deposits, Corporate Debentures, and Bonds where there is low risk but low return. The may invest in Stock of companies where the risk is high and the returns are also proportionately high. The recent trends in the Stock Market have shown that an average retail investor always lost with periodic bearish tends. People began opting for portfolio managers with expertise in stock markets who would invest on their behalf. Thus we had wealth management services provided by many institutions. However they proved too costly for a small investor. These investors have found a good shelter with the mutual funds.

One of the financial innovations which really help the small investors to earn wealth is the concept and design of mutual funds.Fund manager concentrates on risk - return trade off, minimize the risk and maximize the return through diversification of the portfolio.Opportunities of Mutual Funds are tremendous especially when an investment is concerned. A mutual Fund pools money from many investors and invest the money in stocks, bonds, short term money market instruments, other securities or assets, or some combination of these investments. The combined holdings of the mutual Fund owns are known as its portfolio. Each unit represents an investor's proportionate ownership of the fund's holdings and the income those holdings generate. Mutual fund industry has seen a lot of changes in past few years with multinational companies coming into the country, bringing in their professional expertise in managing funds worldwide. In the past few months there has been a consolidation phase going on in the mutual fund industry in India. Now investors have a wide range of Schemes to choose from depending on their individual profiles.Because of the large number of mutual fund companies and schemes, retail investors are facing problems in selecting right funds. Also, it is of paramount importance for policy makers, governing bodies and mutual fund companies to analyze as which schemes are efficient performers. One of the main reasons for poor growth is the lack investors' trust on companies and policy makers. Therefore, for promoting the growth of Indian mutual fund industry, it is very crucial to understand the investors' behavior towards different investment options and for mutual funds

\section{REVIEW OF LITERATURE}

For those investors who does not have enough time and expertise to analyse and invest in stocks and bonds, mutual funds offer a viable investment alternative, as mutual funds provide the benefit of cheap access to expensive stocks. Mutual Fund diversify the risk of the risk of the investors by investing in a basket of assets. A team of professional fund managers manage them with in-depth research inputs from investment analysts. A number of studies have been conducted in India and abroad covering different aspects of Mutual fund.

V.Rathnamani (2013) explains that many investors are preferred to invest in mutual fund in order to have high return at low level of risk, safety liquidity. The world of investment has been changing day to day, so investor's

\footnotetext{
${ }^{1}$ Lecturer in Commerce, St. Xavier's College for Women, Aluva.

${ }^{2}$ Retd.Principal NSS Hindu College, Changanacherry. 
preferences toward investment pattern also changed. In the demographic profile most of the investors are willing to invest only $10 \%$ in their annual personal income, around $39 \%$ of investors belongs to age range of 31 to 40 years. In this study investors are willing to take moderate and low level risk; most of the investors belong to moderate investment style.Vanniarajan T. and GurunathanP.,(2007) analyzed some factors in their work on "Investment in Mutual funds: A Customer Centric Analysis" emphasizes that MF companies are focusing on customized products due to hectic competition. The study focuses on important factors leading to investment in mutual funds which are monetary, core product, fund strength, promotional measures, customer expectations and service quality.AnjanChakarabarti and Harsh Rungta (2000) stressed the importance of brand effect in determining the competitive position of the AMCs. Their study reveals that brand image factor, though cannot be easily captured by computable performance measures, influences the investor's perception and hence his fund/scheme selection.According to SEBI - NCAER Survey (2000), households preference for instruments match their risk perception; Bank Deposit has an appeal across all income class; $43 \%$ of the non-investor households equivalent to around 60 million households (estimated) apparently lack awareness about stock markets.

\section{STATEMENT OF THE PROBLEM}

In today's technologically advanced world, as a part of women empowerment, the women has come to manifold in different sectors of economy contributing in pace with the men, in the growth and development of a country. In this scenario it is crucial to study the pattern of savings avenues of employed women and their perception towards mutual fund, which helps to moldinvestment avenues accordingly. The study was carried on to understand the preference pattern of the women investor so as to understand the perception of the investors towards their investment pattern considering the various factors such as demographic factors, savings pattern, and opinion and so on in today's world women.

\section{OBJECTIVES OF THE STUDY}

The following are the important objectives of the study:

- To understand the women investors preference for Mutual Funds.

- To find out the reasons for the selection of Mutual Fund as an investment alternative.

- To assess their perception regarding Mutual Fund.

- To understand the potential customers and their requirements.

\section{HYPOTHESIS}

Based on the above objectives the following hypothesis was formulated There is no significant relationship between period of investment and return."

\section{METHODOLOGY}

The study has been conducted on the basis of primary data and secondary data. Primary data for the study were collected through distributing structured questionnaire to 30 women investors in Kochi city. Convenient sampling was used to select the sample respondents. Secondary data for the study were collected mainly through journals, books, and websites.

Tools and Techniques used for the study.

Primary data was collected through questionnaire. Ranking of investment avenues were made on the preference of investors. Mathematical tools like Ratios and Percentages were used. Chi square technique was used to test the hypothesis.

ANALYSIS AND RESULTS 
TABLE SHOWING INVESTMENT AVENUES

TABLE NO 1

\begin{tabular}{|l|l|l|l|}
\hline SL NO: & AVENUES & N0.0FRESPONSES & PERCENTAGE (\%) \\
\hline 1 & BANKDEPOSIT & 28 & 25.45 \\
\hline 2 & SHARES & 14 & 12.72 \\
\hline 3 & DEBENTURES & 0 & 0 \\
\hline 4 & MUTUALFUND & 30 & 27.27 \\
\hline 5 & DERIVATIVES & 0 & 0 \\
\hline 6 & GOVT.SECURITIES & 6 & 5.45 \\
\hline 7 & REALESTATE & 4 & 3.63 \\
\hline 8 & GOLD & 18 & 16.36 \\
\hline 9 & POSTOFFICE & 10 & 9.09 \\
\hline & TOTAL & 110 & 100 \\
\hline
\end{tabular}

SOURCE OF DATA: PRIMARY DATA

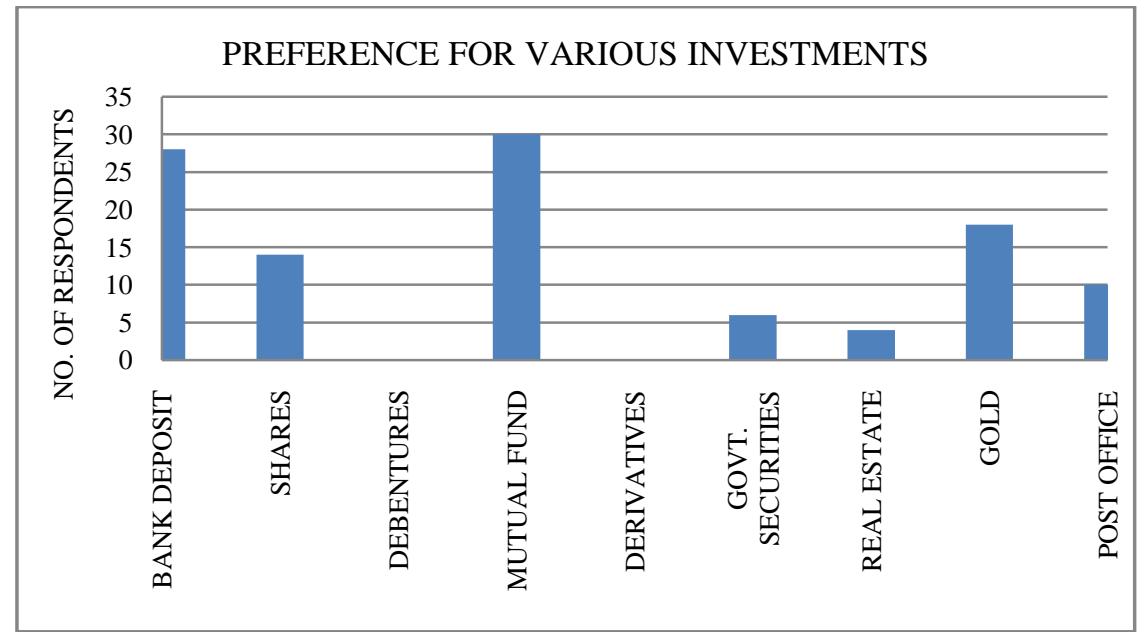

FIGURE NO 1

The table 1 shows preference forvarious avenues of investment, Bank Deposit secures the prime position followed by Mutual Fund (27.27\%), Gold (16.36\%), Shares (12.72\%), Post office (9.09\%), Government securities $(5.45 \%)$ and Real Estate $(3.63 \%)$. But none of the investors are interested in Debentures and Derivatives.

TABLE SHOWING MOST ATTRACTED FEATURES

\begin{tabular}{|l|l|l|l|}
\hline SL NO. & FEATURES & NO. OF RESPONSES & PERCENTAGE(\%) \\
\hline 1 & DIVERSIFICATION & 6 & 20 \\
\hline 2 & BETTER RETURN \& SAFETY & 19 & 63.33 \\
\hline 3 & REDUCTION IN RISK & 2 & 6.66 \\
\hline 4 & TAX BENEFIT & 3 & 10 \\
\hline & TOTAL & 30 & 100 \\
\hline
\end{tabular}

SOURCE OF DATA: PRIMARY DATA

TABLE NO 2 


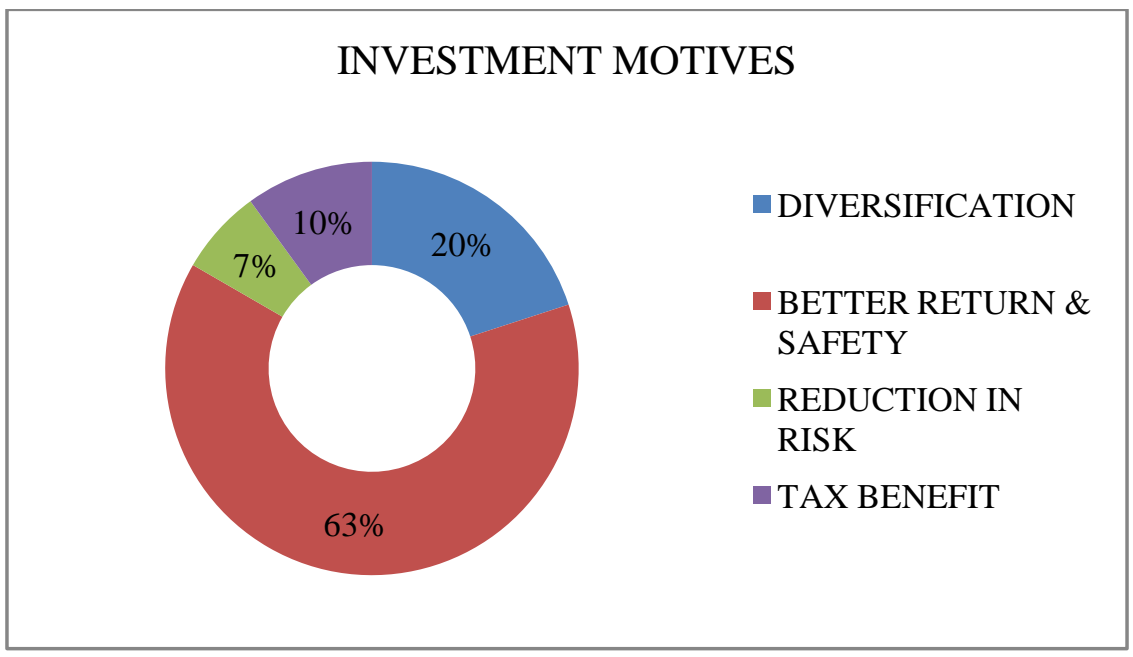

FIGURE NO 2

It is obvious from the table 2, that more than half of the investors opinioned that the motive behind their investments in Mutual Fund are better return and safety (64.29\%), followed by Diversification (21.43\%), 7.14\% of investors opted tax benefit and reduction in risks.

For testing the hypothesis $\mathrm{X}^{2}$ test is used.

\section{HYPOTHESIS}

$\mathrm{H}_{0}$ : There is no significant relationship between period of investment and return.

$\mathrm{H}_{1}$ : There is significant relationship between period of investment and return.

RESULT OF CHI SQUARE TEST

\begin{tabular}{|l|l|}
\hline PARTICULARS & Value \\
\hline Table value & 3.841 \\
\hline Calculated value & 13.05 \\
\hline Level of significance & .05 \\
\hline Degree of freedom & 1 \\
\hline
\end{tabular}

TABLE NO 3

As the calculated value is more than the table value, we reject the $\mathrm{H}_{0}$.

It proves that there is significant relationship between period of investment and return.

\section{RESULTS}

- $40 \%$ of the respondents fall in the group below 30.More than half of the respondents are private employees, $47 \%$ of investors are earning an income of 2-5 lakhs. And majority of them are married.

- $27.72 \%$ of investors have invested in Mutual Fund. The preference for mutual fund shows the gained popularity among the women investors. But they are reluctant to invest in recent financial instruments like derivatives.

- Majority of the investors invested $10-30 \%$ of their incomes.

- More than half of investors opined better return and safety are the motives behind their investment.

- Majority of the investors monitored the investment to stay updated and to act accordingly.

- $44.44 \%$ of investor invested with a view of wealth creation.

- Half of investors prefer to receive return through Growth in NAV. But none insist on Dividend re investment.

- Depending on the purpose of investment, investors are ready to invest in short, medium, long term investment plan.

- Only minor group of investors are ready to undertake high level of risk. And rest of them preferred to play a safe game.

- More than half of investors belong on category of satisfied level of return.

- $43.33 \%$ of investors were aware only of specific scheme of investment. But none of them is totally ignorant.

- Majority of investors are satisfied with return of long term investment.

- It proved that there is a significant relationship between period of investment and return. 
- Majority of investors have plans to re-invest in mutual fund.

\section{CONCLUSION}

The Mutual Funds have gained much popularity among the women investors. Investors are attracted towards it because of its higher return and growth in Net Asset Value. Based on the purpose of investment, investors opted short, medium as well as long term schemes. It is revealed from the study that there is a significant relationship between period of investment and level of satisfaction on returns. Investors are much cautious about their investment that they continuously monitor their investments and tend to select only much reliable schemes. The levels of satisfaction reflect their decision to re-invest in Mutual Funds by majority of the investors.

\section{SUGGESTIONS}

1. Asset Management Companies should try to build strong image in public and should provide better services to investors as these are shown to be given due importance by the investors.

2. Investors can make their investment in Systematic Investment Plans to ensure the safety of returns.

\section{REFERENCES}

[1] V. Rathnamani (2013), “Investor's Preferences towards Mutual Fund Industry in Trichy"IOSR Journal of Business and Management (IOSR-JBM) ISSN: 2278-487X. Vol.6.

[2] Manju G (2012), “Investors Perception Towards Indian Stock Market”, Journal of Banking,Information Technology and Management. Jaipur, Vol. 9, (1).

[3] L.D. Vaikunthe and S.M. Salimath (2011), "Mutual Fund:The Challenges and Issues", Southern Economist.

[4] SrivastavaVinay K (2011), "Depositor in Indian Capital Market”, Advancement in Management, monthly journal, Indore, vol. 4(5) .

[5] Goelsarita\& Jain S.K (2010), "Investment avenues in Financial Market”, International Journal of Business Management, Economics and Information Technology, New Delhi ,vol.2(1) .

[6] Vanniarajan T. and Gurunathan P. (2007), "Investment in MFs: A Customer Centric Analysis", Indian Journal of Accounting, vol.XXXVII No. 2

[7] Ramamurthy B. M. and Reddy S (2005), "Recent Trends in Mutual Funds Industry”, SCM and Journal of Indian management, vol. 2 (3).

[8] AnjanChakrabarti and Harsh Rungta (2000), "Mutual Funds Industry in India : An indepth look into the problems of credibility, Risk and Brand", The ICFAI Journal of Applied Finance, Vol.6(2).

[9] SEBI - NCAER( 2000), “ Survey of Indian Investors”, SEBI, Mumbai

\section{BOOKS}

\section{BIBLIOGRAPHY}

Shanmugham, R. 2000, "Factors influencing Investment Decisions", Indian Capital Markets: Trends and Dimensions (ed.), Tata McGraw-hill Publisihing Company Limited, New Delhi, 2000.

Bharati V. Pathak, “The Indian Financial System ”, Pearson Education Publishing, New Delhi, 2010.

\section{ARTICLES}

V. Rathnamani (2013), "Investor's Preferences towards Mutual Fund Industry in Trichy"IOSR Journal of Business and Management (IOSR-JBM) ISSN: 2278-487X. Vol.6.

Manju G (2012), “Investors Perception Towards Indian Stock Market”, Journal of Banking,Information Technology and Management. Jaipur, Vol. 9, (1).

L.D. Vaikunthe and S.M. Salimath (2011), "Mutual Fund:The Challenges and Issues”, Southern Economist. SrivastavaVinay K (2011), "Depositor in Indian Capital Market”, Advancement in Management, monthly journal, Indore, vol. 4(5) .

Goelsarita\& Jain S.K (2010), “Investment avenues in Financial Market”, International Journal of Business Management, Economics and Information Technology, New Delhi ,vol.2(1) .

Vanniarajan T. and Gurunathan P. (2007), "Investment in MFs: A Customer Centric Analysis", Indian Journal of Accounting, vol.XXXVII No. 2

Ramamurthy B. M. and Reddy S (2005), “Recent Trends in Mutual Funds Industry”, SCM and Journal of Indian management, vol. 2 (3).

AnjanChakrabartiand Harsh Rungta (2000), "Mutual Funds Industry in India : An indepth look into the problems of credibility, Risk and Brand”, The ICFAI Journal of Applied Finance, Vol.6(2). 
SEBI - NCAER( 2000), “ Survey of Indian Investors”, SEBI, Mumbai.

\section{WEBSITES}

www.sebi.com

www.rbi.com

www.amfiindia.com

WwW.cic.com

www.indiainfoline.com

www.mutualfundindia.com

www.moneycontrol.com

www.prudentialchannel.com

www.icraindia.com 